\title{
Reimagining a Solitary Landscape: Tracing Communities of Care in Exodus 1-2 and the Film Shirley Adams
}

\author{
Charlene VAN DER WALT (STELlENBOSCH UNIVERSITY) AND JUDITH \\ TERblanche (UNIVERSITY OF THE WESTERN CAPE)
}

\begin{abstract}
The 2009 film, Shirley Adams, directed by the South African director, Oliver Hermanus, depicts Shirley as the lone caregiver to her son, a victim of gang violence on the Cape Flats (South Africa) which rendered him physically disabled and emotionally scared. The film is used as a lens to explore the intersectionality of poverty, violence, gender, class, race, and disability within the South African society. The film's intimate portrayal of Shirley in her efforts to care for her son leaves the viewer without any illusion of the problems facing caregivers. Shirley's solitary effort to embody hope in a stark situation of despair is contrasted with the life giving possibilities contained within so called "communities of care." The community in Exod 1-3 that forms around Moses as identified by Feminist Biblical Scholars is used as an illuminating example. This paper explores the intertextual dialogue between two seemingly distant texts as Shirley Adams enters into creative conversation with a imaginative group of women creating a community of care around one who is helpless and vulnerable. The essay facilitates this interaction between film and Bible text by dynamically shifting in focus between the two distant story landscapes and in the process ultimately imagines an alternative reality for the seemingly isolated Shirley Adams.
\end{abstract}

KEYWORDS: Disability, Shirley Adams, Gender, Race, Exodus 3, Film studies

\section{A INTRODUCTION}

Shirley Adams ${ }^{l}$ is not an easy film to watch as it instills within the viewer, almost from the opening scene, the overwhelming sense that something has got to change, that things cannot continue in the same desperate mode. The isolation and vulnerability of Shirley's position as primary caregiver to her fragile

* Article submitted: 14/01/2016; accepted: 5/04/2016. Charlene van der Walt \& Judith Terblanche, "Reimagining a Solitary Landscape: Tracing Communities of Care in Exodus 1-2 and the Film Shirley Adams," OTE 29/1 (2016): 176-194. DOI: http:// dx.doi.org/10.17159/2312-3621/2016/v29n1a11

1 Shirley Adams, directed by Oliver Hermanus (2009; Cape Town: DV8 Films, 2011), DVD. 
tetraplegic son, Donovan, is so intensely depicted that the despair of the situation is almost tangible to the viewer. Shirley's story haunted me long after the end credits of the film disappeared from the screen and it was especially her painful isolation that stayed with me after my initial engagement with the film. Her isolation came into even sharper focus when I discovered the community of care constructed around Moses in the biblical narrative of Exod 1-2 illuminated by Feminist Biblical Scholars. Claassens unpacks the community of relational care:

... in Exodus 1-2, one finds evidence of how human dignity is preserved in the way five women responded to acts that violated the sanctity of human life. The relational care exercised by the midwives Shiphrah and Puah, Moses' mother and sister, and the daughter of the Egyptian Pharaoh, in protecting the lives of the community's most vulnerable members, serves the function of resisting the actions of a cruel empire set on destroying life. ${ }^{2}$

The paper strives to read together these two seemingly distant narratives as one which is situated within the biblical tradition and the other which originates from the contemporary South African landscape. The ultimate aim or goal of this creative intertextual reading is not to come to a final or correct analysis of the intent of the individual narratives, but rather to allow the narratives to dynamically inform the creative process of sense making and meaning making. I would like to echo the words of the remarkable Spanish writer Alberto Manguel when he elaborates on the human capacity for reading:

I believe that we are, at the core, reading animals and that the act of reading, in its broadest sense, defines our species. We come into the world intent on finding narrative in everything: in the landscape, in the skies, in the faces of others, and, of course, in the images and words that our species creates. We read our own lives and those of others, we read the societies we live in and those that lie beyond our borders we read pictures and buildings, we read which lies between the covers of books. ${ }^{3}$

2 L. Juliana M. Claassens, "Resisting Dehumanization: Acts of Relational Care in Exodus 1-2 as Image of God's Liberating Presence," Scriptura 105 (2010): 573.

3 Alberto Manguel, A Reader on Reading (New Haven, Conn.: Yale University Press, 2010), 10. De Gruchy alludes to the same when stating: "From the beginning of history we humans have told stories, whether in word, dance, drama or painting, to make sense of our place in the world; stories about our origins, who we are, why the world is like it is, and how we should live ... Telling such stories is a necessary and potent way of handing on wisdom from one generation to another, one culture to another, about our common humanity and distinct personal identities." See John W. de Gruchy, Being Human: Confessions of a Christian Humanist (London: SCM, 2006), 4. 
Besides enabling us to make sense ${ }^{4}$ of the world, narratives also help us to live and structure our lives in such a manner as to experience a deep sense of meaning. While facilitating a creative act of dynamic interaction between the two stories in question, I simultaneously propose that the narratives become important reflective surfaces for contemporary readers. The messy, complex, painful and often muddled world depicted in narratives, through the act of reading and interpretation, becomes a reflective surface for ethical reflection by contemporary readers. In deducing ethical pointers from biblical narratives I take my cue from the work of Jacqueline Lapsley who states:

For the most part I want to move away from asking which characters are worth emulating or not, and which text is "good" or "bad." As a rule, the kind of ethical reflection I propose here asks the reader to allow herself [sic] to be drawn into a complex moral world evoked by the narrative. In the narrative worlds of the Old Testament easy moral judgments are elusive and most often miss the mark. The kind of ethics I envision has more to do with how the reader enters into the story - it is narrative ethics - and less to do with the reader standing outside the story making ethical judgments about character. ${ }^{5}$

It is important to note that Lapsley's understanding of narrative ethics is rooted in the emotional response of the reader to the text and the reader's capacity to empathise with the characters in the story.

In the first part of the paper I would like to facilitate a creative dialogue between the two stories. At the centre of each of these narratives we find a vulnerable boy. In Exodus it is the baby Moses that is dependent on acts of relational care for survival, where in Shirley Adams we find the fragile Donovan facing life-denying realities. Both stories are concerned with the preservation of life and illuminate the creative and often risky strategies employed by women in order to resist dehumanising circumstances.

In the final part of the paper I would like to reflect on a challenge that the combined reflective surfaces of the narratives pose to contemporary read-

4 Ackermann illuminates this sense making dimension of narratives when stating: "Telling stories is intrinsic to claiming one's identity and in the process finding impulses for hope . . . Narrative has a further function. Apart from claiming identity and naming the evil, narrative has a sense-making function. The very act of telling the story is an act of making sense of an often incomprehensible situation, of a suffering and chaotic world in which people wrestle with understanding and in so doing seek to experience relief." Denise M. Ackermann, Tamar's Cry: Re-Reading an Ancient Text in the Midst of an HIV/AIDS Pandemic (Johannesburg: Ecumenical Foundation of Southern Africa, 2001), 18-19.

5 Jacqueline E. Lapsley, Whispering the Word (Louisville: Westminster John Knox, 2005), 11. 
Van der Walt \& Terblanche, "Reimagining," OTE 29/1 (2016): 176-194 179

ers: the so called ... "so what?" question of the analysis. By starting with a contextual reflection and again bringing the conversation back to the contemporary realities of modern interpreters, I am trying to take up the challenge from Denise Ackermann when she states:

A feminist theology of praxis begins with the critical analysis of a given contexts and a particular focus on how gender roles are understood and lived out. It then seeks to engage contextual situations with liberating and transformative praxis in order to encourage human flourishing, undergirded by the belief that such theology is done in service of furthering God's reign on earth. ${ }^{6}$

\section{B SHIRLEY ADAMS, PORTRAIT OF A SOLITARY MOTHER}

Firstly, I will turn my attention to the less well known story of the two, namely the film Shirley Adams. ${ }^{7}$ The film is a simple, unflinching reflection of one woman's reality on the cape flats. Tlelima states:

Shirley Adams is a heart-warming film about a middle aged-colored woman struggling to take care of her recently disabled son, Donovan. Her name is Shirley Adams. She lives in Mitchell's plain. She has no money, no job and her husband has left her. ${ }^{8}$

The film, shot on location in Mitchell's Plain, part of what is termed the "Cape Flats," and located on the urban peripheries of the city of Cape Town, South Africa, depicts the harsh realities that Shirley Adams needs to negotiate daily in order to make some kind of life for herself and her now disabled son. It is a stark film that honestly engages with characters caught in seemingly unchangeable situations of hopelessness. The camerawork is close, almost too close, and there is no escaping the despair that this film portrays.

The film beautifully depicts the complex intersection ${ }^{9}$ of disability, ${ }^{10}$ poverty, violence, race, class and gender. This complex examination is of importance, because, as Tony Emmet states

6 Denise M. Ackermann, "From Mere Existence to Tenacious Endurance: Stigma, HIV/AIDS and a Feminist Theology of Praxis," in African Women, Religion, and Health: Essays in Honor of Mercy Amba Ewudziwa Oduyoye (ed. Isabel A. Phiri and Sarojini Nadar; Maryknoll: Orbis Books, 2006), 227.

7 The film is situated within popular culture and as Crous states films do "not only document a mimetic reality, but are critical commentators about the material conditions of the characters' lives they represent." Marius Crous, "En ek sê is 'n trassie': Perspectives on Afrikaner Homosexual Identity," Agenda 20/67 (2006): 49.

8 Tiisetso Tlelima, "Film Review: Shirley Adams," Arts (24 August 2010), n.p. [cited 21 April 2012]. Online: http://www.artsreview.co.za/bioscope/2010/08/24/filmreview-shirley-adams/.

9 Deckha alludes to academic reflection termed as intersectional when explaining the aim as follows: "theoretical commitment to recognizing how multiple axes of 
... the last decade the relationship between poverty and disability has been strongly established, however, less attention has been devoted to the ways in which disability and illness are intermediated by other inequality's, including gender and race. ${ }^{11}$

Director Oliver Hermanus, who studied Film at the University of Cape Town, first came to public attention with his award-winning 2009 film entitled "Shirley Adams."12 Shirley Adams was the product of Hermanus's Masters Studies at the London Film School where he studied after receiving a bursary from the acclaimed Hollywood director, Roland Emmerich. ${ }^{13}$

The uncompromising engagement that the film depicts is noticeable right from the opening sequence of the film. The camera is right on top of Shirley as she tries to revive Donovan after a first suicide attempt. The long, intense sequence sets the tone for the rest of the film. The film subtitled "Portrait of a Mother" depicts Denise Newman in the title role in long sequences of being. She is portrayed mostly with the camera behind her head or peaking over her shoulder, caring diligently for her tetraplegic son, Donovan, who has been wheelchair bound for 10 months after a gang related shooting incident. Shirley's life revolves around the care of her son. She bathes him, feeds him, carries him, silently keeps him company, and, in the words of Weingarten

differences coalesce to shape human experiences of injustice." Maneesha Deckha, "Intersectionality and Posthumanist Visions of Equality," WJLGS 23/2 (2008): 249.

10 Care for individuals and families affected by embodied disabilities in the public health care system have to be considered against the historical realities that gave rise to the current system. "Racial and gender discrimination, the migrant labour system, the destruction of family life, vast income inequalities, and extreme violence have all formed part of South Africa's troubled past, and all have inexorably affected health and health services." Hoosen Coovadia, et al., "The Health and Health System of South Africa: Historical Roots of Current Public Health Challenges." Lancet 374/9692 (2009): 817-834.

11 Tony Emmett, "Disability, Poverty, Gender and Race," in Disability and Social Change: A South African Agenda (ed. Brian Watermeyer; Cape Town: HSRC Press, 2006), 207.

12 Hermanus, the Cape Town born, South African writer/director, has subsequently been noted for Skoonheid (Beauty), the 2011 film that was the first Afrikaans film to be screened and the Cannes Film Festival and won the Queer Palm for its contribution to Queer cinema in 2011.

13 Sanger describes Hermanus's project as follows: "A film that focused on the intimate relationship between a mother and her disabled son - a survivor of a shooting - caught in the cross-fire of gang violence in the community where he lives." Nadia Sanger, "Review Essay on Oliver Hermanus' Shirley Adams," Agenda 25/4 (2011): 18. 
Van der Walt \& Terblanche, "Reimagining," OTE 29/1 (2016): 176-194 181

(albeit awkwardly), "carries hope for him." 14 Through this process she resists the dehumanising effect of his reality. ${ }^{15}$

Donovan (uncompromisingly played by Keenan Arrison) is complexly portrayed as someone who is struggling to come to terms with his new life realty. He has lived 20-odd years in a "normal body" and consequently the construction of his masculinity has developed in line with his abled body reality. Moolman remarks with regard to the process of identity formation: "In South Africa, colonialism, apartheid and capitalism have shapely influenced personal and collective identities." ${ }^{\text {"16 }}$ Donovan's identity formation, as well as the construction of his masculinity, has been rooted in his embodiment. Donovan, as a young coloured able bodied man, negotiated a complex meta-masculinity framework.

Brittijn remarks: "In most cultures, hegemonic values require that men provide financially for their family, be physically strong and sexually successful." ${ }^{17}$ Moolman continues in terms of the South African context and states that "the dominant notion of South African masculinity is embodied in a white, middle/upper class, heterosexual, breadwinner, provider, father and husband role." ${ }^{18}$ The ideas of hegemonic masculinities are not achievable for all men at all times and for some men they are completely out of reach. Narrowing the contextual focus Salo argues that on the Cape Flats, the emasculation of coloured men initiated under apartheid continues in the post-apartheid era as the dominant definition of masculinity remains one that emphasises men's economic roles. ${ }^{19}$ She maintains that, as coloured working -class men continue to

14 Kathy Weingarten, "Reasonable Hope: Construct, Clinical Applications and Supports," FP 49/1 (2010): 7-9.

15 In her engagement with Exod 1-3, Juliana Claassens refers to the 2003 book The Female Face of God in Auschwitz by Melissa Rafael where she argues that through ordinary acts of caring and washing women were able to resist dehumanisation in the most inhuman circumstances. See Claassens, "Resisting Dehumanization," 573. The same resistance is noticeable in Shirley's care of Donovan. She refuses to give into despair and strives to preserve life for the most vulnerable. Cf. Melissa Raphael, The Female Face of God in Auschwitz: A Jewish Feminist Theology of the Holocaust (London: Routledge, 2003).

16 Benita Moolman, "The Reproduction of an 'Ideal' Masculinity through Gang Rape on the Cape Flats: Understanding Some Issues and Challenges for Effective Redress," Agenda 18/60 (2004): 112.

17 Marianne Brittijn, "We're not Boys Anymore, We Need to Be Courageous: Towards an Understanding of What it Means to Be a Man in Lavender Hill," Agenda 27/1 (2013): 51.

18 Benita Moolman, "The Reproduction," 112.

19 Elaine Salo "'Mans is ma soe': Ganging Practices in Manenberg, South Africa and the Ideologies of Masculinity, Gender and Generational Relations," in States of violence: politics, youth, and memory in contemporary Africa (ed. Edna G. Bay \& 
be excluded from the labour market due to their low levels of education and their lack of appropriate cultural capital, they still cannot become breadwinners of their families. Thus, alternative ideologies of masculinity in the local context has to be found, which, she believes were created around gaging practices. Salo further states:

The gang does not only exist as a means of resistance and of economic survival for its members. Through the rites and practices of ganging these men create and offer each other alternative means and resources to assert their gendered identities as heterosexual men. ${ }^{20}$

Moolman continues:

Lack of power and resources to attain the dominant masculinity resulted in the creation of alternative masculinities amongst black men dispossessed of land employment and political power. The gang and its members simultaneously tried to emulate and oppose the dominant masculinity. Violence or displays of physical "manly" strength became a means of establishing the alternative masculinity. $^{21}$

Values such as strength, dominance and power are reinforced by this physical display of manhood. The dominant meanings of manhood in the Cape Flats extend to ownership of land and bodies.

The competition for acquisition and ownership of land and bodies developed between different groups of men, and remains the case globally as it is radicalized and sexualized. Gang fights over control of territory often referred to as "turf wars' are often also messages of dominance and control being communicated to the community and the dominant hegemonic masculinities. $^{22}$

It is within this context and against this backdrop that Donovan's identity developed and his ideas about what it means to be a man and a human being were established. From what is to be gathered from the film, Donovan was not himself part of a gang, but rather is a tragic victim of above mentioned turf wars as a stray bullet rendered him disabled.

Donald L. Donham; USA, Charlottesville, Virginia, University of Virginia Press, 2007), 148-178.

Cited 21 April 2012. Online: http://www.csvr.org.za/wits/confpaps/salo.htm\#note1.

20 Salo, "Ganging Practices" 152.

21 Moolman, "The Reproduction," 113.

22 Venitha Pillay "Masculinities and mergers: Losing ground through territoriality," Gender \& Education, 18/6 (2006), 606. 
Van der Walt \& Terblanche, "Reimagining," OTE 29/1 (2016): 176-194 183

Donovan is experiencing the loss of his body and consequently the loss of his manhood and personhood. He is visibly repulsed by his own body and turns his head away with a grimace on his face as Shirley tenderly washes his body. He voices something of his internalised stigmatisation when he comments on a friend's early departure after a visit: "He seker just wanted to see what a gebreklik (cripple) looks like." Donnie has internalised one of the common misconceptions regarding disability. Reynolds comments on this misconception: "Disability often signifies the way that some people are recognized as lacking something basic to what is understood as human, being abnormal, a body gone wrong. ${ }^{, 23}$ Disability according to this construction is viewed as a tragic flaw. ${ }^{24}$

Beyond the stigmatisation by others, Donovan cannot stand his own body and defines himself as one who is lacking (in line with major societal trends). His repulsion is further fuelled by the abandonment of his father. Donnie explains his father's departure by saying: "He left, because he could not stand me anymore ..."

Donnie's hopelessness and despair floods the screen as we often encounter him in a motionless position wordlessly brooding on his loss, as he suffers to find space in his own self-understanding for the inclusion of his body and fails to incorporate the realty of his new bodily experience in his self-construction.

Trying, however awkwardly and not without shortcomings, to hold hope for Donnie, we find Shirley Adams. Shirley negotiates the harsh realities of the Cape flats and her life represents the intersection of a number of complex issues. I will briefly refer to some of these issues.

Firstly, after Donovan's father's departure we find Shirley (as so many other women) in a female headed household. ${ }^{25}$ Brittijn elaborates on this trend:

23 Thomas E. Reynolds, "Theology and Disability: Changing the Conversation," in Searching for Dignity: Conversations on Human Dignity, Theology and Disability (ed. Julie Claassens, Leslie Swartz and Len Hansen; Stellenbosch: African SUN Media, 2013), 82.

24 Claassens picks up on the challenge that these misconceptions hold for people living with disabilities when stating: "Probably one of the most daunting challenges facing people living with disabilities is the stereotypes and misguided perceptions regarding disability that pervade society today." L. Juliana M. Claassens, "Job, Theology and Disability: Moving Towards a New Kind of Speech," in Searching for Dignity: Conversations on Human Dignity, Theology and Disability (ed. Julie Claassens, Leslie Swartz and Len Hansen; Stellenbosch: African SUN Media, 2013), 55.

25 Sanger continues: "Shirley's story is not uncommon on the Cape Flats: many women are primary caretakers of children, while many men are absent from the 
It is not known how many children and youth grow up in femaleheaded households in communities on the Cape Flats, but the commonly held view is that men are largely absent from family and community life or "negatively" present in the form of a strong-held identity with gangster cultures. ${ }^{26}$

Secondly, Shirley is unemployed due to the demands of Donnie's full time care. Although she had a steady job and secure source of income, she needed to give it up in order to take care of her son.

Thirdly, Shirley is poverty stricken. ${ }^{27}$ In one of the most harrowing scenes of the film we follow Shirley frantically through the packed isles of a Shoprite $^{28}$ store, shoplifting to get necessary expensive items for Donnie's care. Our pulses start to race as we watch with Shirley as a man is escorted away in front of her for the same crime as the one she is in the process of committing. The life Shirley carves out for her and her son is simple and comes down to the basics as is clearly visible from the simple food they eat.

Fourthly, we see Shirley negotiating the lack of a sufficient public transport system. The viewer often finds Shirley mind-numbingly waiting for public transport or spending large amounts of time in transit. Due to the lack of infrastructure it also seems impossible for her to access the state sponsored health care system. Shirley finds herself in a complex bind; in order for her to get access to Donovan's medication, he needs to be present to see the doctor, but Shirley has no way of getting Donnie to the doctor. This is not only due to a lack of transport, but also because he is not willing to sit in long queues at the hospital and in the process becoming a spectacle that everyone can stare at.

Finally, we find Shirley negotiating the every present threat of violence. Shirley and Donnie live on a typical Cape Flats street, behind burglar-bars and security gates. The viewer often encounters her while she is walking on the narrow stoep smoking a cigarette and hearing gunshots in the distance. Although the film is shot on location in the Cape Flats, the location is completely under-

family. The labour Shirley performs constantly as a single mother is unrelenting." Sanger, "Review Essay," 20.

26 Brittijn, "We're Not Boys Anymore," 51.

27 Swartz, Harding and De Lannoy state the following regarding inequality in South Africa: "South Africa currently rates as the eighth most unequal society in the word, with $21 \%$ of its population living on less than $\$ 1$ a day and $47 \%$ of the population existing below that minimum living income level (under ZAR 600 or $\$ 75$ a month). Of those who are described as poor, using the Apartheid racial classification system, $93,3 \%$ is black, $6,3 \%$ are coloured, $0.4 \%$ are Indian, and $0,1 \%$ are white." See Sharlene Swartz, James H. Harding and Ariane de Lannoy, "Ikasi Style and the Quiet Violence of Dreams: A Critique of Youth Belonging in Post-Apartheid South Africa," CompEd 48/1 (2012): 27.

28 Shoprite is a middle to low income food store chain in South Africa. 
Van der Walt \& Terblanche, "Reimagining," OTE 29/1 (2016): 176-194 185

stated and only appears in passing wide angled shots or in occasional pass-by's. Maybe it is exactly this understatedness that makes it impossible to escape the oppressive realities of this landscape. You cannot see it, but you can feel it and you instinctively know (as Shirley and Donnie knows) that it is a landscape that you cannot escape.

\section{THE CONSTRUCTION OF A COMMUNITY OF CARE IN EXODUS 1-2}

As is the case in Shirley Adams, we find a story that at its heart holds a vulnerable boy and shows the lengths towards which caregivers would go to ensure the wellbeing and life of the ones who are most vulnerable in Exod 1-2. ${ }^{30}$ The seeming isolation in which Shirley strives to care and preserve the life of Donovan led me to the biblical story of Moses around whom we find a bustling community of courageous women who repeatedly made life affirming compassionate choices in order to preserve life.

The people of Israel find themselves in the dehumanising grip of slavery and forced labour in Egypt due to a new Pharaoh's anxiety and paranoia:

Time severs the connection between the Egyptian leadership and the Israelites: Joseph is dead and there is a new king in Egypt who no longer has a personal connection to the Hebrews. As is so often the case, an interpersonal relationship with a representative of the "Other" can serve to humanize the entire group, the lack of relationship can dehumanize the entire group. ${ }^{31}$

29 The engagement with the biblical text mainly focuses on the "community of care" that has been identified by predominantly Feminist Biblical Scholars when five individual women cross boundaries to preserve life. This is by no means a comprehensive engagement with the richly complex narrative found in Exod 1 and 2. For further reading see amongst others: Brevard S. Childs, The Book of Exodus: A Critical, Theological Commentary (OTL; Philadelphia: Westminster John Knox Press, 1974); Michael Goldberg, "Exodus 1:13-14," Int 37/4 (1983): 389-391; Scott Morschauser, "Potters' Wheels and Pregnancies: A Note on Exodus 1:16," JBL 122/4 (2003): 731-733 and Donald W. Wicke, "The Literary Structure of Exodus 1:2-2:10." JSOT 7/24 (1982): 99-107.

30 The book of Exodus may be a surprising choice, especially considering the South African apartheid legacy where the "chosen" people appropriated the story in a way as to claim God's protection and care for themselves over against the ones that had to be conquered. But, I would in line with Lapsley's suggestion like to listen to the life giving alternative values that are whispered in the first three chapters of the book ... The story told in Exod 1-3 simultaneously relies on human constructions of identity and undermines those very categories through the transgressive acts of deliverance performed by the women.

31 Lapsley, Whispering, 70. 
The anxiety felt by the Pharaoh stems from the remarkable fertility and subsequent increase in population experienced by the people of Israel in Egypt. $^{32}$ The Pharaoh fears that the rapid population growth of the people of Israel would pose a threat to his power if they grow too numerous and powerful and side with other enemies in order to overthrow his regime in Egypt. Nancy Lee importantly remarks regarding the rhetoric employed by the Pharaoh: "Pharaoh's paranoid scapegoating of the Hebrews, then, is the ground for his policy of genocide; to implement it he implicates his own people and believes he will have their support in carrying it out.",33

In order to deal with this threat of Israelite proliferation the Pharaoh employs three different and escalating cruel strategies to curtail this growth. Cheryl Exum notes the three strategies employed by the Pharaoh to deal with the people of Israel: firstly with harsh labour, secondly through coopting the midwives Shiphrah and Puah to kill all the newborn Hebrew boys, and thirdly through male child infanticide. ${ }^{34}$ When considering the movement of the text Exum states:

By means of this narrowing of focus, the text turns our attention away from the multitude with which it began ("the sons of Israel were fruitful . . . and the land was filled with them") and directs it to the one who will play an instrumental role in attaining the freedom of YHwH's "first-born son" (4:22), Israel. ${ }^{35}$

The strategies employed by Pharaoh repeatedly and ironically fail. In the first instance the extreme labour forced on Israel which is meant to stunt the population growth has the direct opposite result. Secondly, Shiphrah and Puah, the Hebrew midwives or midwives to the Hebrews, ${ }^{36}$ disobey Pharaoh's direct

32 Fretheim alludes to the fertility language uses in the text: "Five verbs are used to stress an extraordinary increase in numbers ... This language connects with the promise of fruitfulness to Israel's ancestors (cf. Gen. 17:2-6;48:4), the fulfilment of which is anticipated in Gen. 47:27. Still further language of growth is used as the chapter progresses $(1: 9,10,12,20)$, highlighting the fulfilment of promises made to this family." See Terence E. Fretheim, Exodus (IBC; Louisville, Ky.: Westminster John Knox, 1991), 24-25.

33 Nancy Lee, "Genocide's Lament: Moses, Pharaoh's Daughter, and the Former Yugoslavia," in God in the Fray: A Tribute to Walter Brueggemann (ed. Tod Linafelt and Timothy K. Beal; Minneapolis: Fortress Press, 1998), 68.

34 Cheryl J. Exum, “'You Shall Let Every Daughter Live': A Study of Exodus 1.82.10," Semeia 28 (1983): 67.

35 Exum, "“You Shall Let Every Daughter Live,"” 67.

36 The text is ambiguous about the identity of the midwives. Lapsley remarks: "Either Shiphrah and Puah are Egyptians tending to the Hebrew women ('the midwives of the Hebrew women'), or they are Hebrew women doing the same. If they are indeed Egyptian women then the theme of crossing ethnic boundaries to effect deliverance makes its first appearance in the story here. In either case, the ambiguity 
Van der Walt \& Terblanche, "Reimagining," OTE 29/1 (2016): 176-194 187

command to kill the boys at the moment of birth when they are most vulnerable and explain their failure when confronted by Pharaoh by speaking into his prejudice.

The king likely already thinks of the masses of Hebrews as animals, in the negative sense of less than human, so that he is not inclined to doubt the veracity of the women's account. We can see him nodding his head in response to their claim, "Yes, that makes sense given what I know of them." 37

Carol Meyers comments on the strategy used by the women when confronted by the powerful ruler of Egypt when stating:

They exonerate themselves by deception, a theme that appears frequently in the Hebrew Bible; the needs of a subordinate group or individual are achieved against the will of a more powerful figure by wiliness rather than force. ${ }^{38}$

The covert solution proposed by appropriating the services of the midwives becomes overt when Pharaoh orders that all male children be cast into the Nile. The ironic climax of the narrative presents itself when it is the daughter of the Pharaoh that crosses ethnical, class, and race boundaries in order to save the life of Moses. It is important to note that Pharaoh becomes undone in the narrative by those that he disregards when conceiving his master plan of oppression.

Rentia Weems elaborates on this fundamental oversight when stating:

He assumes that the births of male and female children have some profoundly different social and political implications. That is, male children pose a more dire physical threat to the empire than do female children ... At the story's end, the assumption that male children are more of a threat than female children, and in turn that men pose more of a threat to and empire than women, is not only exposed but also ridiculed. ${ }^{39}$

in the text announces ethnic difference as a significant theme in the story by forcing the reader to ponder the implications of identity." Lapsley, Whispering, 72. Exum also alludes to the ethnicity of the midwives when concluding: "In its very ambiguity, the text moves beyond nationalistic concerns to bear witness to the power of faith to transcend ethnic boundaries." Exum, "“You Shall Let Every Daughter live,"” 72.

37 Lapsley, Whispering, 74.

38 Carol Meyers, Exodus (NCBC; Cambridge: Cambridge University Press, 2005), 37-38.

39 Rentia J. Weems, "The Hebrew Women Are Not Like the Egyptian Women: The Ideology of Race, Gender and Sexual Reproduction in Exodus 1," Semeia 59 (1992): 29-30. 
Life is preserved in the Exod 1-2 narrative by five women who are willing to take risks, cross boundaries and respond with empathy, compassion and care to the most vulnerable in society. The relational acts of care by these women transform them from courageous individuals to a community of care when "the women, Hebrew and Egyptian, conspire to save the most vulnerable members of society, here represented by a baby." 40

The transformation from individual caregivers to a community of care comes into sharp focus when the story climaxes into the deliverance of Moses. Within the community of care different role-players are confronted with unique challenges determined by their distinctive situatedness and their relationship to the one who is in need of care. The foundation for the community of care is a sense of awareness of the fragility of life and an understanding of common human vulnerability.

Moses' mother and primary caregiver is challenged into taking an almost unthinkable risk when ironically doing exactly that what the Pharaoh orders: putting her beautiful baby in a basket and placing him in the Nile. In order to preserve his live, she had to "let him go" and painfully acknowledge the limitations of her own resources and ability to care for the baby considering her precarious position.

Exum remarks with regard to Moses' mother:

A negative situation is introduced: she is able to hide him no longer. Her reaction takes the form of increased activity. She takes a papyrus ark, "bitumens" it with bitumen and pitch, places the child in it, and places it in the reads along the edge of the Nile. Al this activity on her part underscores the mother's concern for her child and her resourcefulness in caring for him. ${ }^{41}$

No psychological insight is offered regarding the mother's motive but her actions make clear that she is determined to act in order to preserve the life of her child. It is important to note that the possibility of life for the baby Moses begins when his mother admits the limits of her ability to protect him by herself and as a result takes a risk that allows for the community of care to develop. Pharaoh's daughter, upon seeing the baby and hearing him cry, is filled with compassion and simultaneously confronted with an impossible

\footnotetext{
40 Lapsley, Whispering, 79.

41 Exum, "'You Shall Let Every Daughter Live,"” 76. Exum comments on the intertextual link between the Noah and Moses stories by stating: "Commentators have not failed to note the connection and draw a parallel between Noah and Moses as deliverers who are rescued for death by drowning; a further parallel may be drawn between Noah who builds the ark that saves humanity and Moses' mother who builds the ark that saves the future deliverer of Israel."
} 
Van der Walt \& Terblanche, "Reimagining," OTE 29/1 (2016): 176-194 189

choice: let the baby live and directly disobey the command decreed by her father, or choose obedience to death by denying life.

Nancy Lee remarks regarding the risk taken by the "outsider" to the oppressed ethno-religious community:

She must cross dangerous social and ethnic boundaries to help, regardless of her father's pervasive policy. Her radical action cannot be overstressed. In the ancient Near East, this common literary figure who reaches out to save the child in jeopardy is not depicted as belonging to a different ethnic group, rarely is it a figure of royalty, and rarely a women. ${ }^{42}$

Moses' sister, from her position of lookout and portraying the role of protector, is challenged to speak life to power by proclaiming an inventive solution to the predicament faced by the Pharaoh's daughter. ${ }^{43}$ All of these women take risks, all cross boundaries, all open themselves up for new possibilities in order to preserve life.

\section{A CASE OF SHARED VULNERABILITY}

At the outset of this enquiry I thought that Shirley Adams's story was one of isolation that stood in stark contrast to the community of care that one finds in Exod 1-2 when a diversity of women cross boundaries and take risks in order to unite in the undertaking to saving lives. I read Shirley and Donnie as the solitary victims of the intersections of disability, violence, poverty, race and gender in a contemporary fragile South African setting. But after a number of viewings of the film and the intertextual reflection with the Exodus story I discovered a community of care around Shirley and Donovan. Surely not a perfect community, and maybe not the one one would expect or wish for, but a community of care none the less. A community made up by the culturally removed others and unexpected collaborators.

The unexpected intercultural community of care consists of, amongst others, Kariema and Kariem, the elderly Muslim neighbours of Donnie and Shirley, who try to help out where they can with lifts to and from the hospital and general acts of neighbourly concern. Kariema further assists Shirley by looking after Donnie when she has to make the trip to the city and by acting as a conversation partner for Shirley, offering words of encouragement and concern. Further from the centre we find Dr. Willemse, Shirley's previous white,

\footnotetext{
42 Lee, “Genocide's Lament," 74.

43 Lapsley remarks the following regarding Miriam's life giving suggestion: "Although by all social, political, and economic standards within the text Pharaoh's daughter has all the power and Miriam has none, Miriam has on her side rhetorical power, the power to mold the moral response of someone more privileged and powerful than she." Lapsley, Whispering the Word, 78.
} 
upper-class, educated employer, who seems willing to help but whom Shirley fails to engage in her hour of need. Thirdly, we find Tamsin Graner, probably one of the most interesting characters in the film. She is described by Donnie as "a typical white girl" as she manifests all the stereotypes of a young white middle class do-gooder. She is assigned to Donnie's case as part of her medical studies. If one can look beyond painful cultural and class misunderstandings, it is clear that Tamsin really only wants to help. But she is in over her head. Her remarks regarding Donnie's diet and the need for inclusion of fish and fresh fruit and vegetable sends Shirley into a fit of rage as she ushers Tamsin out the door with the words: "Do you see any fish here ..." It is clear that Tamsin and the Adams family live in different worlds although they are all inhabitants of the City of Cape Town. One sees this when Tamsin returns to the Adams house with fish and fruit in Woolies ${ }^{44}$ bags, or as she tries to draw Donnie out of himself by showing him photos of her family's trip to Italy . . . clearly a reality worlds away from the one that Donnie is experiencing. Regardless of all these glaring displays of cultural and class misunderstandings, it is one of the rare conversations between Donnie and Shirley that speaks to the heart of the matter. After stating that he finds that "Tamsin is all right," Shirley responds by saying: "She is scared of me, I think." To this Donnie replies: ". . Y Ya, you mos like scaring people . . always wanting to be in control . .."45

To my mind this little interaction speaks to the heart of the situation that Shirley finds herself in. Shirley has the incapacity to show her own vulnerability and to help Donnie to understand his own bodily impairment as a manifestation of common human vulnerability. I would like to argue that this is the case because the entire system is so fixated on Donnie's disability in the light of the disability construction where impairment is considered as a flaw, as something gone wrong, as a deficit. Shirley and Donnie are isolated in the creation of an "us-versus-them" binary. Us, being somehow blemished, tainted or out of place versus all the others (the big faceless cult of normalcy) who are without vulnerability. Within this construction Shirley finds herself and Donnie isolated and excluded. The existential realisation of collective vulnerability is lacking from Shirley's construction of reality as she cannot integrate "the inescapable fact that we are born, live our lives, and then die as vulnerable creatures exposed to and needing each other."

\footnotetext{
44 Woolworths is an upper class food chain store in South Africa.

45 Donovan's observation is reinforced by Hermanus's shooting style as Sanger remarks: "Shirley has an uncompromising stance: she seems guarded - her body disallowing intrusions, acting as an obstruction to the viewer. She is protective of herself, her environment, and her son. This visual style invokes feelings of claustrophobia, and in the context of Shirley's lived reality, works to create a narrative where the mediation of class violence and gender intersect. Shirley is set up as the embodiment of the female-mother who carries the trauma of structural violence on herself, as well as her son." Sanger, "Review Essay," 19.

46 Reynolds, "Theology and Disability," 20.
} 
Van der Walt \& Terblanche, "Reimagining," OTE 29/1 (2016): 176-194 191

L'Arche community, eloquently sums it up when stating: "We do not discover who we are, we do not reach true humanness, in a solitary state; we discover it through mutual dependency, in weakness, in learning through belonging.,"

Viewed through the lens of basic vulnerability, "neediness" or "lack of ability" is not a flaw detracting from an otherwise pure and complete human nature. Reynolds continues when arguing:

Rather, it is testimony to the fact that we - all human beings receive our existence form each other. And recognizing this is a source of relational openness to others, who are in turn similarly constituted. Genuine wholeness is found not through bodily completeness or ability, but through an acknowledgment of vulnerability that is made concrete in relations of mutual giving to and receiving from others. ${ }^{48}$

As a result of Shirley's inability to conceive of collective vulnerability, she is closed to the potential of the gifts of a diverse, intercultural community of care or a community of fellow vulnerable ones. Crossing borders, or allowing for border crossings to take place, is painfully impossible for Shirley. The anxiety and despair resulting from Donnie's isolated situatedness and his lack of experience of a community of fellow vulnerable ones see him making one of only two independent choices showing his agency in the film; Donnie decides that he no longer wants to live and drowns himself in the bathtub. ${ }^{49}$

However, Shirley's own journey shows more hopeful potential as she crosses the boundary and visits the mother of Jeremy Jacobs, the boy who confesses to being the one who shot Donnie. Something of their collective vulnerability is expressed when Filda Jacobs laments their communal disposition as she reaches out to Shirley and states ... "Our boys used to play together in the yard, Shirley ..."

47 Jean Vanier, Becoming Human (Mahwah, N. J.: Paulist Press, 1998), 41.

48 Reynolds, "Theology and Disability," 22

49 In a heartbreaking scene in the film we see the awkward unacknowledged community of care gathered around Donnie as he celebrates his birthday. Donnie is present but seems oddly on the outside ... as if he does not belong there. It is clear in retrospect that Donnie has already decided to end his life at this point. For Donnie it is impossible to imagine a new life - he cannot make peace with his new way of being in the world, he cannot embrace his vulnerability. 


\section{E CONCLUSION}

By reading the two stories together a variety of responses to common human vulnerability come into focus. In Exodus we find a community of care developing when women are willing to take risks and cross boundaries to preserve life. In Shirley Adams we are confronted with the complex and painful depiction of isolation as Shirley and Donovon struggle to come to terms with their dependency on others and their need for care and community.

When we read these stories together the reflective surface confronts us with our own awareness and negotiation of the human disposition of vulnerability. Our own situatedness is challenged and confronted by the vulnerability of Donnie's disabled body and the helplessness of the baby Moses. We are again confronted with the ethics of hospitality and care as we are challenged to identify with our own vulnerability and simultaneously pursue community precisely because of this vulnerability. We are challenged to invite and to be invited because we are again reminded of the fact that we do not do our life in isolation. We don't go at it alone ...

\section{BIBLIOGRAPHY}

Ackermann, Denise M. Tamar's Cry: Re-Reading an Ancient Text in the Midst of an HIV/AIDS Pandemic. Johannesburg: Ecumenical Foundation of Southern Africa, 2001.

. "From Mere Existence to Tenacious Endurance: Stigma, HIV/AIDS and a Feminist Theology of Praxis.” Pages 221-42 in African Women, Religion, and Health: Essays in Honor of Mercy Amba Ewudziwa Oduyoye. Edited by Isabel A. Phiri and Sarojini Nadar. Maryknoll: Orbis Books, 2006.

Brittijn, Marianne. "We're Not Boys Anymore, We Need to be Courageous: Towards an Understanding of What It Means to be a Man in Lavender Hill." Agenda 27/1 (2013): 49-60.

Childs, Brevard S. The Book of Exodus: A Critical, Theological Commentary. Old Testament Library. Philadelphia: Westminster John Knox Press, 1974.

Claassens, L. Juliana M. "Resisting Dehumanization: Acts of Relational Care in Exodus 1-2 as Image of God's Liberating Presence." Scriptura: International Journal of Bible, Religion and Theology in Southern Africa 105 (2010): 572580.

"Job, Theology and Disability: Moving Towards a New Kind of Speech." Pages 55-66 in Searching for Dignity: Conversations on Human Dignity, Theology and Disability. Edited by Julie Claassens, Leslie Swartz and Len Hansen. Stellenbosch: African SUN Media, 2013.

Coovadia, Hoosen, Rachel Jewkes, Peter Barron, David Sanders and Diane McIntyre. "The Health and Health System of South Africa: Historical Roots of Current Public Health Challenges." The Lancet 374/9692 (2009): 817-834.

Crous, Marius. "'En ek sê is 'n trassie': Perspectives on Afrikaner Homosexual Identity." Agenda 20/ 67 (2006): 48-56.

De Gruchy, John W. Being Human: Confessions of a Christian Humanist. London: SCM, 2006. 
Van der Walt \& Terblanche, "Reimagining," OTE 29/1 (2016): 176-194 193

Deckha, Maneesha. "Intersectionality and Posthumanist Visions of Equality." Wisconsin Journal of Law Gender and Society 23/2 (2008): 249-267.

Emmett, Tony. "Disability, Poverty, Gender and Race." Pages 207-233 in Disability and Social Change: A South African Agenda. Edited by Brian Watermeyer. Cape Town: HSRC Press, 2006.

Exum, Cheryl J. “'You Shall Let Every Daughter Live': A Study of Exodus 1.8-2.10.” Semeia 28 (1983): 63-82.

Fretheim, Terence E. Exodus. Interpretation: A Bible Commentary for Teaching and Preaching. Louisville, Ky.: Westminster John Knox, 1991.

Goldberg, Michael. "Exodus 1:13-14." Interpretation 37/4 (1983): 389-391.

Lapsley, Jacqueline E. Whispering the Word. Louisville: Westminster John Knox, 2005.

Lee, Nancy. “Genocide's Lament: Moses, Pharaoh's Daughter, and the Former Yugoslavia." Pages 66-82 in God in the Fray: A Tribute to Walter

Brueggemann. Edited by Tod Linafelt and Timothy K. Beal. Minneapolis: Fortress Press, 1998.

Manguel, Alberto. A Reader on Reading. Connecticut: Yale University Press, 2010.

Meyers, Carol. Exodus. New Cambridge Bible Commentary. Cambridge: Cambridge University Press, 2005.

Moolman, Benita. 'The Reproduction of An 'Ideal' Masculinity through Gang Rape on the Cape Flats: Understanding Some Issues and Challenges for Effective Redress." Agenda 18/60 (2004): 109-124.

Morschauser, Scott. "Potters' Wheels and Pregnancies: A Note on Exodus 1:16." Journal of Biblical Literature 122/4 (2003): 731-733.

Pillay, Venitha. "Masculinities and mergers: Losing ground through territoriality." Gender \& Education 18/6 (2006): 591-612

Raphael, Melissa. The Female Face of God in Auschwitz: A Jewish Feminist Theology of the Holocaust. London: Routledge, 2003.

Reynolds, Thomas E. "Theology and Disability: Changing the Conversation." Pages 17-30 in Searching for Dignity: Conversations on Human Dignity, Theology and Disability. Edited by Julie Claassens, Leslie Swartz and Len Hansen. Stellenbosch: African SUN Media, 2013.

Elaine Salo “"Mans is ma soe': Ganging Practices in Manenberg, South Africa and the Ideologies of Masculinity, Gender and Generational Relations," in States of violence: politics, youth, and memory in contemporary Africa (ed. Edna G. Bay \& Donald L. Donham; USA, Charlottesville, Virginia, University of Virginia Press, 2007), 148-178. Cited 21 April 2012. Online: http://www.csvr.org.za/wits/confpaps/salo.htm\#note1.

Sanger, Nadia. "Review Essay on Oliver Hermanus' Shirley Adams." Agenda 25/ 4 (2011): 18-23.

Shirley Adams. Directed by Oliver Hermanus. 2009. Cape Town: DV8 Films, 2011. DVD.

Swartz, Sharlene, James H. Harding and Ariane de Lannoy. "Ikasi Style and the Quiet Violence of Dreams: A Critique of Youth Belonging in Post-Apartheid South Africa." Comparative Education 48/1 (2012): 27-40.

Tlelima, Tiisetso. "Film Review: Shirley Adams." Arts Review (24 August 2010). No Pages. Cited 21 April 2012. Online: http://www.artsreview.co.za/bioscope/2010 /08/24/film-review-shirley-adams/. 
194 Van der Walt \& Terblanche, "Reimagining," OTE 29/1 (2016): 176-194

Vanier, Jean. Becoming Human. Mahwah, N.J.: Paulist press, 1998.

Weems, Rentia J. "The Hebrew Women Are Not Like the Egyptian Women: The Ideology of Race, Gender and Sexual Reproduction in Exodus 1." Semeia 59 (1992): 25-34.

Weingarten, Kathy. "Reasonable Hope: Construct, Clinical Applications and Supports." Family Process 49/1 (2010): 5-25.

Wicke, Donald W. "The Literary Structure of Exodus 1:2-2:10.”Journal for the Study of the Old Testament 7/24 (1982): 99-107.

Dr. Charlene van der Walt, Department of Old and New Testament, Stellenbosch University, charlenevanderwalt@sun.ac.za

Judith Terblanche, Department of Accounting, University of the Western Cape, jterblanche@uwc.ac.za 